\title{
Influence of weather factors on insect and mite pests infesting French bean (Phaseolus vulgaris L.), Assam, India
}

\author{
D. SHARMAH*, S.RAHMAN ${ }^{1}$, P. DEBNATH ${ }^{2}$ AND A. KHOUND ${ }^{3}$
}

Krishi Vigyan Kendra (ICAR), SOUTH TRIPURA (TRIPURA) INDIA

${ }^{1}$ Department of Entomology, Assam Agricultural University, JORHAT (ASSAM) INDIA

${ }^{2}$ Department of Plant Pathology, Assam Agricultural University, JORHAT (ASSAM) INDIA

${ }^{3}$ Department of Horticulture, Assam Agricultural University, JORHAT (ASSAM) INDIA

\section{ARITCLE INFO}

Received : 01.02 .2017

Revised : 23.03 .2017

Accepted : 28.03.2017

\section{KEY WORDS :}

French bean, Insect, Mite pests, Infestation, Weather parameters, Correlation
*Corresponding author:

dasharmah@gmail.com

\begin{abstract}
A field experiment was carried out in the Integrated Crop Research (ICR) farm, Assam Agricultural University, Jorhat to determine the impact of weather parameters on insect and mite pests infesting French bean (Phaseolus vulgaris L.) during 2013-14 and 201415. The weather parameters had a significant impact on population build up of various French bean crop pests. Cutworm population found to be positive and significant correlation with morning relative humidity $(\mathrm{r}=0.573)$ during $2014-15$ while aphid showed a positive significant correlation with maximum temperature $(\mathrm{r}=0.555)$ and $\mathrm{BSSH}(\mathrm{r}=0.671)$ but negative with relative humidity $(\mathrm{r}=-0.562 *)$ in $2013-14$. Two spotted spider mite (TSSM) population showed a positive significant correlation with morning relative humidity $\left(\mathrm{r}=0.661^{*}\right.$ and $\left.\mathrm{r}=0.617^{*}\right)$ in both the years and negative correlation with maximum temperature ( $\mathrm{r}=0.603$ and $\mathrm{r}=559)$ in 2013-14 and 2014-15, respectively. Anegative significant correlation with maximum temperature $(\mathrm{r}=706)$ and positive correlation with relative humidity ( $\mathrm{r}=568$ ) with pod borer population during 2013-14. The rain fall $(\mathrm{r}=589)$ had a negative significant correlation with Thrips population during 2013-14. Whitefly population found to be negative significant correlation with maximum temperature $(\mathrm{r}=554$ and $\mathrm{r}=553)$ and positive correlation with morning relative humidity $(\mathrm{r}=605$ and $r=674$ ) in 2013-14 and 2014-15, respectively. This present findings will certainly be a helpful tool for profitable cultivation of French bean crop by forecasting insect and mite pests arrival as well as management point of view.
\end{abstract}

How to view point the article : Sharmah, D., Rahman, S., Debnath, P. and Khound, A. (2017). Influence of weather factors on insect and mite pests infesting French bean (Phaseolus vulgaris L.), Assam, India. Internat. J. Plant Protec., 10(1) : 157-166, DOI : 10.15740/HAS/IJPP/10.1/ 157-166. 